\title{
CONFLICT AVOIDANCE BY INTERNATIONAL AGREEMENT
}

\author{
WILLIAM RALPH LEDERMAN*
}

INTRODUCTION

Each modern national state has a rather well developed set of legal principles whereby some account is taken of foreign as well as domestic laws in settling the legal relations of persons concerned in factual situations with foreign as well as local features. These are the rules of "private international law" or "conflict of laws," socalled, and understanding of their technical nature and their purpose is crucial to assessing what is possible in the way of conflict avoidance by international agreement. Of course, the very object of these national systems of conflictual rules has been and is basically conflict avoidance. That is to say, they represent attempts to avoid the evil of investing the same persons with different (or conflicting) legal rights and duties in the two or more countries touched by a given international factual situation. These national conflictual systems have, in the main, developed domestically without sanction or benefit of international agreements, and the results (though certainly far from perfect) have been significant. Nevertheless, it will be contended here that further advances in the utility and justice of this branch of the law in any country require international or interstate agreement. But international agreements could do more harm than good if they failed to take account of the basic features of technique and policy that have characterized the various national conflictual systems. Accordingly, the analysis that follows seeks to reveal these essential features in an orderly way and to educe their necessary implications respecting effective conflict avoidance by international agreement. For the most part, the writer will speak in terms of the English system of conflictual rules because, so far at least as British Commonwealth countries are concerned, private international law is still primarily a department of the common law where English judges have led in developing the rules. Also, to speak in terms of the English private international law avoids the peculiar impact of any particular federal constitution on interstate or interprovincial conflict avoidance within that federation.

What, then, have we learned about the extent to which practical national legal procedures can be devised to take account of foreign laws with the object of conflict avoidance when dealing with international facts? The basic problem is to determine which countries are potentially concerned and then to make a choice between the

* B.A. 1937, LL.B. 1940, University of Saskatchewan; Rhodes Scholar I939, B.C.L. I948, Vinerian Scholar 1948, Oxford University. Member of the Saskatchewan and Nova Scotia bars; Sir James Dunn Professor of Law, Dalhousie University Formerly Assistant Professor of Law, University of Saskatchewan. Contributor to legal periodicals. 
respective national legal solutions which are thereby found to be competing to govern the solution of the juridical issue in question. Thus, the rules for choice of law are fundamental, and so their nature must be our concern. To understand them, we must first distinguish classification of facts from classification of laws and then distinguish also indicative from dispositive rules. The inevitable conflictual dilemma of classification will then be examined and the steps necessary for its solution suggested. There must be brief notice of the problems that arise from a comprehensive reference to foreign law (renvoi and secondary classification). Finally, certain inferences and conclusions deducible from the preceding analysis will be offered with special reference to the part international agreement might play in futhering conflict avoidance in the sense explained.

\section{II}

\section{Classification of Facts and Laws: General Consideratrons}

Certain basic considerations of analytical jurisprudence must be our first concern, and their nature has been well described by Sir Frederick Pollock in a passage in which he clearly differentiates classification of laws from classification of facts: ${ }^{1}$

It is not possible to make any clear-cut division of the subject-matter of legal rules. The same facts are often the subject of two or more distinct rules, and give rise at the same time to distinct and different sets of duties and rights. The divisions of law, as we are in the habit of elliptically naming them, are in truth divisions not of facts but of rules; or, if we like to say so, of the legal aspect of facts. Legal rules are the lawyer's measures for reducing the world of human action to manageable items, and singling out what has to be dealt with for the time being, in the same way as number and numerical standards enable us to reduce the continuous and everchanging world of matter and motion to portions which can be considered apart.

By enlarging upon the last sentence of this quotation for the moment, more light can be shed on the nature of the legal classification of facts. Rules of law are precepts of human conduct employed as a means of social control in a politically mature community. They must deal with such nonlegal realities or facts as persons, things, conduct, and states of mind. They discriminate between different kinds of persons and things, different kinds of conduct and states of mind, for purposes of defining the entitlement of the persons concerned to certain legal rights, privileges, powers, or immunities. In other words, rules of law are reducible to the formula, "If so and so is the fact, John ought to act in this way." The words expressing the first part of this formula comprise the fact-category and must be appropriate to designate things which exist or have happened. The second part of the formula is the valuejudgment, setting forth what ought to be the behavior of the person or persons designated, given the existence or occurrence of the kind of facts described. There is much more to an ordinary rule of law, then, than simple description of facts, and hence the necessity of distinguishing the classification of facts from the classification

${ }^{1}$ Frederick Pollock, A First Book on Jurisprudence 81 (3d ed. 19ir). 
of laws. This distinction will be more fully developed later. At the moment, a further analysis of the classification of facts is in order.

The fact-categories of rules of law may be quite detailed or very general; but in any event, they are conceptual or notional, and as such, must be distinguished from real facts-things which exist or have happened. Thus, when a client comes to a lawyer with his story and his problem, the lawyer's first step in the process of legal decision is, in effect, to put himself this question: Of which categories or classes of facts in the law do these concrete facts constitute a particular instance? The accurate answer to this question (on a purely local fact situation) brings about the selection of the legal rules appropriate, whereupon the prescription of legal result they contain applies. For example, $X$ agrees in writing to buy $Y$ 's land for \$rooo. Here we have concrete facts relevant to the fact-categories of consensus and consideration in the English law of contract, and by virtue of this subsumption, it is prescribed that in this case, $X$ and $Y$ must, as a matter of law, keep their respective promises. As laws are expressed in words, in subsuming real facts under laws, we are really concerned with the problem of language itself, that of the meaning of words in relation to nonverbal realities. As Dr. Glanville Williams has put it: "... the law is only a special department of language and ... whereas the application of law is limited, language is all-pervasive." Thus, the legal classification of facts in this sense is an important element in any process of legal solution; and as John Austin reminds us in his Jurisprudence, this matching of facts with factcategories is often far from easy: "The difficulty is in determining not what the law is or what the fact is, but whether the given law is applicable to the given fact." This determination is a matter of deciding relevance, and as Thayer states in his classic work on evidence: "The Law furnishes no test of relevancy. For this it tacitly refers to logic and general experience, assuming that the principles of reasoning are known to its judges and ministers. ..."4

Thus, concrete and real facts constitute the undifferentiated mass of data to be classified by the categories of fact contained in our rules of law. "Fact" and "category" must be distinguished. Real facts, things which exist or have occurred, are, in themselves, legally neutral. They have no inherent legal attributes whatever to give a clue to their legal significance, if any. Their only legal attributes are acquired ones, those which men ascribe to them by subsuming them under laws deemed appropriate. ${ }^{5}$ But if facts are thus neutral, they are also capable of acquiring multiple legal significance. In other words, the same concrete facts may be open to a simultaneous subsumption under different rules of law. The facts of a single automobile accident where the driving was very reckless would be simultaneously appropriate to rules of negligence in tort and the dangerous driving section of the criminal code, to

"Williams, Language and the Law: I, 6I L. Q. Rev. 71 (1945).

${ }^{3}$ I John Austin, Lectures on JuRisprudence 230 (5th ed. I885).

4. B. Thayer, A Preliminary Treatise on Evidence at the Common Law 265 (i898).

"In this regard, note the remarks of Walter W. Cook, The Logical and Legal Bases of the ConFLICT OF LAWS I 82-84 (19.42). 
say nothing of the relevance in addition of certain rules of property and insurance law. It is important to remember this potential multiple impressionability of concrete facts in private international law, where two or more national systems of laws are, in effect, competing to govern a single set of facts. Thus, there can be no objection to submitting a single set of facts provisionally to two different national legal systems for a preview of what rules would be applicable to them in those countries.

Before we leave the legal classification of facts, one final question needs answering. It may be asked: If the legal system in question is embodied in a politically living and valid constitution, are not rights under it just as much real facts as anything else? Do we not state a fact in these circumstances when we say that $X$ owns Blackacre? The answer would be yes, without qualification, if laws automatically applied themselves to nonlegal facts in order to produce legal rights and duties. The truth, of course, is this does not happen. Laws, as ascertained by men, must be applied to nonlegal facts, as perceived by men, in order to determine what rights and duties do obtain under a living legal system. No doubt, in many cases, this is a simple and obvious process, but in many others, it is difficult; and it is these difficulties, with special reference to private international law, that we are attempting to explore here. Once a doubtful legal question has been solved by the person constitutionally authorized to do so, it is doubtless legitimate to speak of the resultant rights and duties as being and having been real facts. However, when our concern is with the processes whereby lawyers, judges, or officials arrive at a determination of legal rights and duties in a given concrete situation, the end result cannot be used as an element in the explanation of its own production. Thus, for our purposes here, finally confirmed rights and duties are not included in the "facts" of which we speak. We are necessarily confined to the facts of the nonlegal world already described.

Let us turn now, by way of contrast, to a general consideration of the classification of rules of law. Of course, classification itself, as a basic procedure, does not alter. It is simply the arrangement into distinct classes of an undifferentiated mass of data by criteria which take account of various attributes inherent in the things concerned. However, as rules of law and concrete facts are different orders of things, obviously the criteria of classification are different, depending on whether facts or laws are the subject-matter being classified. Rules of law respectively attach prescribed rights and duties to some hypothetical condition or state of facts (here called a fact-category) and are, thus, norms, principles, or standards. They are concerned with the "ought" of human conduct, with what should be and not merely what is. The fact-categories they contain, while no doubt suggested by certain real life situations, past, present, or anticipated, are, nevertheless, independent of actual facts. The legal fact-category is, thus, notional and can exist even though concrete facts relevant to it have never occurred, but are merely anticipated. This being so, it is proper and essential to distinguish the classification of laws as a different process from that of the classification of facts. 
Legal rules, then, considered in isolation from concrete facts, may be grouped in various classes by criteria which select uniform features of the concepts they contain, including the rights and duties they prescribe. As Dr. Martin Wolff puts it: "Classification may be compared with the mathematical process of placing a factor common to several numbers outside the bracket." Thus, rules of law may be classified on the basis of some uniform feature of their fact-categories (that is, the classes of persons, things, conduct, or intentions they respectively contain); or on the basis of some uniform feature of the legal results they prescribe (that is, the rights and duties they specify). For example, for purposes of the Canadian constitution, we find that the class "criminal law" is defined as including all rules which, in pith and substance, forbid any conduct in the public interest. ${ }^{7}$ Hence, the criterion of this class is the prohibitive feature common to the legal prescriptions of the rules so grouped. The type of conduct thus prohibited might be any sin of omission or commission. However, more often than not, the grouping of rules in classes depends cumulatively on several criteria. For instance, certain rules are grouped as rules for the sale of goods because their fact-categories are limited to tangible movable things, and their legal prescriptions concern only the transfer for money of the collection of legal rights and privileges which make up "ownership" of such things.

Clearly then, legal rules can be classified by any number of criteria for any number of purposes. There is no one universal system of classification of laws valid for all purposes, though there have been several attempts by jurists to outline systems for which this claim is made. (The schemes of Professor Holland and Albert Kocourek might be cited as examples.) ${ }^{8}$ The true view is that systems of classification will be as various as the purposes which classification may be used to serve. In the words of Dr. Roscoe Pound: "Classification is not an end. Legal precepts are classified in order to make the materials of the legal system effective for the ends of law." The history of the categories "realty" and "personalty" in English law provides an interesting illustration of classification as a tool of policy. "Realty" is a class comprising those legal rules which confer proprietary rights over land to endure for an uncertain period. Thus, there are three criteria which form the basis of this particular class of rules of law: (i) they must be rules concerning rights over land; (ii) these rights must be rights in rem-that is, they must avail against all comers, or nearly so; and (iii) these rights must be uncertain in the length of time for which they are to endure. (This third requirement refers to the well-known common-law doctrine of estates.) It will be noted that rules concerning leasehold rights over land are excluded from the class because the duration of the rights concerned is certain, being fixed between definite dates. Hence, they are characterized as rules of "per-

- Martin Wolff, Private international Law 48 (1945).

${ }^{7}$ See Attorney General for British Columbia v. Attorney General for Canada, [I937] A.C. $368,375$.

${ }^{8}$ Kocourek, Classification of the Law, II N. Y. U. L. Q. Rev. 319 (1934), reprinted in Jerome Hall, Readings in Jurisprudence 615 (1938); T. E. Holland, The Elements of Jurispredence c. 9 (5th ed. r8go).

${ }^{\circ}$ Pound, Classification of Law, 37 Harv, L. Rev. 933, 944 (rg24). 
sonalty": a class which came to include all rules conferring proprietary rights over things (including land) not classifiable as rules of realty. As Pollock and Maitland point out, the classing of rules conferring leasehold rights as rules of personalty served a very definite economic purpose in the $\mathrm{r}^{\text {th }}$ and $\mathrm{r}^{\text {th }}$ centuries. In medieval England, land was the principal form of wealth, and "real" rights over land were not freely transferable, being fettered by all the rigidities of the feudal system. For instance, prior to 1540 , they were not freely alienable by will. On the other hand, proprietary rights over chattels could be freely disposed of by will, and, thus, by classifying leasehold rights over land as personalty, a valuable and freely bequeathable form of investment in land was made available. Originally then, this peculiar legal dichotomy of "realty" and "personalty" enabled the law to satisfy a genuine economic need in medieval England. ${ }^{10}$

Perhaps it will have been noticed that we have just been speaking of the classification of legal rights as well as of rules of law. This should not be confusing if it is remembered that only laws can confer legal rights, "and hence, a classification of rights is, ipso facto, a classification of laws, whether the laws concerned are being considered in relation to concrete or hypothetical facts. Again, Sir Frederick Pollock's words are apt: "The divisions of law ... are in truth divisions not of facts but of rules; or, if we like to say so, of the legal aspect of facts."

Now usually schemes of classification result from the meditations of jurists and derive what authority they have from the prestige of their respective authors. In this regard, the English conflictual rules for the choice of law display rather unique features. They necessarily incorporate a complete system for the classification of laws. Consider, for illustration, the following examples of them:

(I) The formal validity of a marriage is determined by the law of the country where the ceremony takes place.

(2) Succession to proprietary interests in immovables, on the death of the owner, is determined by the law of the country where the immovable is situate.

(3) Procedure is determined by the law of the country which is the forum of the action.

(4) Capacity to marry is determined by the law of the country which is the intended matrimonial home.

(5) The essential validity of a contract is determined by the law of the country to whose law the parties in fact intended, or as reasonable men would have intended, to submit their transaction.

Here we find the concepts "form," "substance," "procedure," "capacity," "marriage," "proprietorship," "succession," and "contract." Many more like them would be turned up if the whole range of English conflictual rules were examined. The important point for present purposes is that these are all categories or classes of legal rules. They are not categories or classes of nonlegal facts. Hence, concrete facts

\footnotetext{
${ }^{10}$ See 2 Frederick Pollock and Frederic W. Maitland, The History of English LaW I16, 117
} (2d ed. 1898$)$. 
alone cannot provide the mass of data appropriate for grouping under these categories, since facts, as such, are legally neutral. This may be clearer if we restate the rules in more accurate terms as follows:

(I) The rules for the formal validity of a marriage correspond to those of the law of the country where the ceremony takes place.

(2) The rules for succession to proprietary interests over immovables, on the death of the owner, correspond to those of the law of the country where the immovable is situate.

(3) The rules of procedure are those of the law of the country of the court.

(4) The rules for capacity to marry correspond to those of the law of the country which is the intended matrimonial home.

(5) The rules for the essential validity of a contract correspond to those of the law of the country to whose law the parties in fact intended, or as reasonable men would have intended, to submit their transaction.

Thus, it can be seen that only a mass of particular legal rules can supply the necessary undifferentiated data for grouping under such classes as "rules for succession," "rules for capacity," and so on. There are normative or prescriptive elements involved in the criteria upon which these classes depend, and concrete nonlegal facts are simply not appropriate data, having no such attributes. Facts, in themselves, cannot be "procedural" or "substantive," though particular legal rules appropriate to concrete facts can be one or the other.

We have now come to one of the most important distinctions which needs to be made in this analysis: that between indicative and dispositive rules of law. This requires a closer examination of the nature of a conflictual rule for the choice of law. If we take the rule just quoted about the formal validity of marriage as an example, we find that it contains three elements: (i) a class of legal rules-those which deal with the formal validity of marriage; (ii) a class of pure fact-the country which is the place of the ceremony; and (iii) the prescription of legal result-that the rules applied in England to settle the formal validity of a marriage are to correspond to those of the country which was the place of the ceremony, to the exclusion of any other country's principles.

It can readily be seen why this rule is indicative or selective. In relation to a specific set of concrete facts, it would not itself supply the answer "formally valid marriage" or "formally invalid marriage"; rather, it simply refers authoritatively to another body of rules of law which will answer this question. These other rules are dipositive rules because their terms are such that, applied to particular facts, they will give the answer "validly married" or "not validly married," so far as form is concerned. They are dispositive because they finally dispose of the problem of defining the personal rights and duties of the parties concerned. Conflictual choiceof-law rules, then, enable us to choose between the alternative bodies of possibly applicable dispositive laws, but they do not themselves define personal rights and 
duties. Rather, they contain classes of other rules-classes of dispositive rules-which will do so; hence, the aptness of their description as indicative or selective.

There is only one respect in which actual concrete facts can be directly relevant to choice-of-law rules-or, to put it the other way around, there is only one respect in which conflictual choice-of-law rules can be directly applied to real facts-and that is for definition of the legally significant place elements those facts include. As we have seen, these are the only classes of straight facts which selective rules contain - "the country of the ceremony," "the country which is the domicile of the parties," etc. Hence, the only concrete facts which can be given a legal class or aspect by choice-of-law rules themselves are factual place elments, and this is simply a particular case of the legal classification of facts discussed earlier. For instance, "domicile" is one of these peculiar legal fact-categories, being an amalgam of two types of factual place elements: (i) where a person intends to live, and (ii) where he has been or is physically present. (We need not enter upon the further refinement of the definition of domicile here.) English private international law determines for itself that these are the factual place elements legally significant for certain of its peculiar selective purposes. As Mr. Justice Russell tells us in the case of $\mathrm{Re}$ Annesley: $:^{11}$

... the question whether a person is or is not domiciled in a foreign country is to be determined in accordance with the requirements of English law as to domicil, irrespective of the question whether the person ... . has or has not acquired a domicil in the foreign country in the eyes of the law of that country.

It must be emphasized that the distinction between indicative and dispositive rules is basic for the analysis here being developed, for if facts (other than place elements) cannot be classified by subsumption under indicative rules, they can only be classified by subsumption under dispositive ones. Now the only place fully dispositive legal rules can be found (in the field of personal private rights) is within the domestic legal system of some national state-the body of laws applied within a particular country to sets of facts which display no place elements foreign to that country. In other words, the only sources of dispositive rules capable of impressing legal character on "raw" facts are these domestic national legal systems. This is inevitably the position in a world which has not a true supernational or international dispositive law of private rights.

\section{III}

\section{The Classification Dilemma and Steps Necessary to Choice of Law}

The foregoing reasoning about the classification of facts and laws brings us now to the central dilemma of any system of private international law. In terms of particular examples, it may be explained as follows: One of the choice-of-law rules tells us that if the formal validity of a marriage is in question, we refer to the law

${ }^{21}$ Re Annesley, [1926] Ch. 692, 705. 
of the country where the ceremony occurred; but how are we to decide that our concrete facts do raise the juridical question of the formal validity of marriage? Likewise, another such rule tells us that if the substantial validity of a contract is in question, the reference is to the law of the country to which the parties intended to submit themselves; but how do we know that the problem is one of contract in the first place, so that it becomes proper to use this test of intention for choice of the finally dispositive law? In general terms, this basic dilemma may be stated as follows: We have to know the juridical nature of the real facts before our conflictual rules for choice of law will indicate the governing dispositive rules or system, and yet only dispositive rules can define the juridical nature of the real facts for purposes of this choice. ${ }^{12}$ This looks like the perfect vicious circle, but a reasonable solution for this conundrum exists. It is true enough that analytically we must distinguish classification of facts and classification of laws, but, nevertheless, both processes are required, working in combination, to solve the foregoing dilemma. Properly combined, these two types of classification will produce a definition of the juridical question raised by particular facts, so that our conflictual choice-of-law rules may become operative and indicate decisively where the answer in terms of final rights and duties is to be found. As we have seen, neither type of classification is peculiar to private international law, but the manner of their employment in combination for the above purpose is rather unique.

Let us suppose that a client has come to a lawyer in England with a story the facts of which have some connection with a foreign country. Assuming that the truth of these facts can be proven, how does the legal adviser decide upon the rights which can properly be claimed, since he can see it is possible that reference to foreign as well as English law may be necessary? The present submission is that four steps are required to select and put into operation the correct conflictual choice-of-law rules, thus effecting a decisive reference to the national law to be used. This procedure depends upon the two basic premises which were developed earlier: (I) that legal classification of facts must be distinguished from classification of rules of law, and (2) that indicative or selective rules of law must be distinguished from dispositive rules of law. On this footing, given a set of real facts with foreign as well as English factual place elements, the steps necessary to legal solution are as follows:

I. Determination of which national legal systems may possibly be applicable to the facts.

The national legal systems possibly applicable can be determined working solely with the concrete facts and English private international law rules. The only categories of facts which these rules contain are those designating the factual place elements which are legally significant for choice of dispositive law. Hence, by legal

\footnotetext{
12 Rabel notices this dilemma, though he would not agree with the reasoning of the present writer regarding its solution. See I ERnst Rabel, The Conflict of LAws $45-46$ (1945).
} 
classification of our facts in this respect, we can ascertain the presence of any connecting factors which our private international law defines and uses for any type of problem. At this point, the whole range of the English legal categories of place elements must be employed, because we will not know which one of them is to be finally decisive until the juridical nature of our problem is revealed at a later stage. However, at least it is possible here, as a first step, to determine which potentially significant place elements are present in our concrete facts and, thus, to indicate the alternative dispositive national legal systems that have to be considered. Let us suppose, for instance, that on the facts, the domicile of the persons concerned is England, that their nationality is Portugese, and that the place of some of the acts in question was France. Domicile and the place of acts are employed as legally significant place elements for some questions by English private international law, but it does not use nationality as a connecting factor. Thus, we learn that we have to consider as possibly applicable the national legal systems of England and France. We also know that the law of Portugal can be disregarded as it has no possibility of being applicable. Hence, though we have not yet ascertained the juridical question raised by our facts, we do know this much: that it is the dispositive laws of England and France which must somewhow give our concrete facts legal character for this purpose.

2. Provisional classification of the concrete facts by the national dispositive laws selected as possibly applicable.

The next step is to submit our concrete facts provisionally for classification by the domestic laws of both England and France. In other words, we simply look ahead to the possible solutions under each of these legal systems. We must, for this purpose, assume the facts to be entirely domestic to England in the one case and to France in the other, for only thus can we be sure of submitting them to dispositive laws, which alone can invest them with legal class or character for purposes of ascertaining the juridical question they raise. A so-called "renvoi situation" is, thus, quite impossible at this preliminary stage. We are here concerned, then, simply with the ordinary process of classification of facts, which the English lawyer can carry out for himself in relation to English domestic law, though some French jurist will need to assist with the process as it relates to French domestic law. There will result from this the selection of all the particular English dispositive rules relevant to these facts and all the particular French dispositive rules likewise relevant to them. We still do not know in which respects English rather than French rules are going to be decisive or vice versa, but at least we have now learned what the alternatives are in terms of possible rights and duties in both countries.

At this point, any one of three different situations may be revealed by a comparison of the effect of the relevant and possibly decisive English and French domestic rules: 
(a) the English and French rules may differ in such a way as to give different results in terms of rights and duties on the concrete facts concerned;

(b) the English and French rules may differ but for their different reasons would give the same results on the concrete facts of the given case; or

(c) the English and French rules may be identical in substance and hence would give the same results on the concrete facts concerned for the same reasons.

In case (a), we have a conflict of laws, and obviously a choice must be made between them if a solution is to be reached. In cases (b) and (c), it may be said that there is no conflicts problem and, thus, that no choice need be made between these two possibly applicable sets of law. For all practical purposes, this is no doubt true, but as a matter of theory, it is still the principles of one country only that are finally applicable. At any rate, we will proceed on the assumption that we have the obvious case in (a).

It should be noticed that we have now assembled a mass of particular dispositive rules of law, both English and French, relevant to the concrete facts, and, thus, we have secured the undifferentiated data for submission to a system of classification of laws. Such classification constitutes the next step in this procedure.

3. The classification of the relevant and possibly decisive dispositive rules of law.

The English and French dispositive rules found to be in conflict in 2(a) are now submitted to the categories of such laws in English conflictual choice-of-law rules for classification as rules of the "form of marriage," "the substantial validity of contracts," "rules of procedure," etc. As these rules are relevant to our concrete facts, they represent the potential legal aspect of those facts in England and France, and, hence, according to the manner in which they are classified, the juridical nature of the question raised by the concrete facts is defined. We may, for instance, find that the English and French dispositive rules in conflict are rules of the form of marriage. Our facts, then, can properly be said to raise a juridical problem or question of the form of marriage.

4. The decisive choice of dispositive law.

It is now a simple matter to select the correct choice-of-law rule, which directs the decisive reference to a particular country's law for determination of the rights and duties of the parties. For instance, if we had discovered at stage 3 that our facts raised conflicts problems both of the form of marriage and the capacity to marry, then the English choice-of-law rules tell us that in so far as these facts raise a question of the form of marriage, they are to be referred to the law of the country which was the place of the ceremony, and in so far as they raise a question of capacity, the issue is to be settled by referring them to the law of the intended matrimonial home. In this way, where there is a conflict of relevant national laws, all legal aspects of the facts are effectively dealt with by the choice of one of these competing legal systems as decisive to the exclusion of the other or others. 
Thus, we have, in these four steps, a procedure which solves the central dilemma of classification in private international law..$^{13}$ For the sake of some conciseness in explaining them, certain points were omitted in the foregoing discussion which now need to be considered. The first of these concerns stage 3, the classification of rules of law. If our conflictual categories of laws, such as "contract," "tort," and "procedure," are to serve the purpose of enabling us to take some account of foreign laws, they must be capable of comprehending not only English domestic legal principles of "contract," "tort," "procedure," and so forth, but analogous foreign legal principles as well. As Dr. Cheshire tells us: "The concepts of Private International Law such as 'contract,' 'tort,' 'corporation' must be given a wide meaning in order to embrace analogous legal relations of a foreign type."14 For example, if the peculiar English requirement of consideration is essential in the private international law definition of "rules of contract," we would never do anything but apply English local rules of contract, and the appearance of taking account of foreign laws would be a mere sham. This might suggest that, in our classification of different national laws for purposes of choosing between then, we must rely on categories or classes which are defined by an international jurisprudence the concepts of which are valid for all legal systems. There are prominent proponents of this view, but the reasons for rejecting it are well expressed by Professor Gutteridge in his recent book on comparative law: $:^{15}$

These concepts can-it is said-be ascertained "by the study of comparative law, which extracts from this study essential principles of professedly universal application-not principles based on or applicable to the legal system of one country only." [quoting Beckett, Classification in Private International Law, 15 BRIT. Y. B. INT'L L. 59 (1934)] . . . This view of the matter cannot fail to make a strong appeal to a comparatively minded lawyer. But it is, nevertheless, one which it is difficult to accept. To begin with, no one appears to have attempted to indicate any principles of this nature, and it would seem that if they exist, they are few in number. Nor if these principles can be ascertained, is it clear to what extent they would help to solve the problem of "qualifications." In any event it does not appear to be feasible to insist on a solution which would demand from judges and practitioners a knowledge of analytical jurisprudence and an experience of the working of the comparative method which few of them are likely to possess.

The answer would seem to be, then, that we must classify by the lex fori-that is, that the definitions of our categories of dispositive laws must be essentially those of English analytical jurisprudence. Nevertheless, the English categories can be used to comprehend foreign laws which have no precise counterpart in England. In considering a particular foreign dispositive rule, an English lawyer or judge need only ask himself: If this foreign rule were a rule of domestic English law, how

${ }^{13}$ The writer first published these views in 195r. See Lederman, Classification in Private International Law, 29 CAN. B. Rev. 3, 168 (I95I). For other views of the classification problem, similar in important ways, see J. D. Falconbridge, Essays on the Conflict of Laws 162 (1947); G. C. Cheshire, Private International Law 47-52, 54-6io (4th ed. 1952); and Harold Marsh, Marital Property in CoNflict of Laws 68-75 (I952).

14 G. C. Cheshire, Private International Law 66 (3d ed. 1947).

${ }^{15}$ H. C. Gutteridge, Comparative Law 58 (ig46). 
would English jurists classify it? It is true that this technique will make specially searching demands on English categories of classification, but, nevertheless, it is thus possible for English-defined classes to comprehend nearly all foreign rules of law.

An example may be taken from the field of contract. In France, certain gratuitous promises are enforceable, whereas English law does not recognize simple promises as enforceable unless a price has been given for them within the meaning of the domestic English requirement for consideration. Does this mean that French rules rendering certain gratuitous promises enforceable cannot be classified as rules of contract? Certainly not, for if there were such rules in English law, they would be called "contractual." This is indicated by the fact that the Law Revision Committee recommended as a reform measure for the English law of contract that it should include rules rendering gratuitous promises enforceable (if seriously intended and written).$^{16}$ Clearly, then, these distinguished English jurists would have no difficulty in classifying French rules to the same effect as "contractual" in the English sense for purposes of English private international law.

Finally, in considering the classification of laws, we have to meet the argument that particular foreign rules cannot be considered apart from the foreign system of classification "native" to them, because otherwise, as Dr. Martin Wolff puts it, they would be falsified. ${ }^{17}$ Is it wrong, then, for the English to classify a French dispositive rule as contractual in the English sense for their private international law purposes, when the French themselves classify it as delictual or tortious in their sense for some purpose or purposes of their own? The answer has been suggested earlier that the same dispositive rules may be classified in several different ways for different purposes, and as the purposes differ, so the various systems of classification are likely to differ. Furthermore, these various systems of classification have equal validity, and there is no natural law of any kind rendering one superior to the other. English private international law simply employs a system of classification devised to implement the English policy of affording recognition to some foreign principles of law in some circumstances, which the English specify. For instance, consider the dispositive rule that a will made by an unmarried person becomes void when that person marries. Looking at English law only, we find that this rule occurs in the Wills Act and not the Marriage Act. ${ }^{18}$ This would suggest that for domestic purposes, it is classified as "testamentary law" or "law of succession." However, there is case authority to the effect that for purposes of English private international law, this same rule is classified as "matrimonial law."19 Turning now to Canada, we find that for purposes of the Canadian constitution, such a rule is classified as a rule of "property and civil rights" and, hence, falls within the legislative powers of the

${ }^{10}$ See G. C. Cheshire and C. H. S. Fifoot, The Law of Contract 7I (1945).

${ }^{17}$ WolfF, op. cit. supra note 6 , at 155 .

${ }^{18}$ Wills Act, I837, 7 WILL. 4 \& I VICT. c. $26, \S 18$.

${ }^{10}$ In re Martin, [1900] P. 211 ; Seifert v. Seifert, 23 D. L. R. 440, 32 ONr. L. R. 433 (1914) (Ont. Sup. Ct. I9r5). 
provinces and outside those of the federal Parliament. ${ }^{20}$ Finally, Dr. Martin Wolff tells us that in Germany, such a rule is deemed to belong to the "law of succession," presumably for both domestic and international purposes. ${ }^{21}$ Logically, this rule is quite correctly classified as testamentary, or successive, or matrimonial, or as concerning property and civil rights, and its particular terms and its aptness to concrete facts remain the same no matter how it is classified. The decision on which of these alternative classifications is to prevail for a given purpose has to be made on appropriate grounds of policy and justice by the legal authority in the state with the constitutional power and duty of decision in this respect. Thus, no falsification is involved in the fact that the different categories or classes of different classification systems may overlap so as rationally to embrace the same dispositive rule.

Returning to an English-French situation for illustration, the main point is that our French jurist, as an expert witness considering concrete facts, can tell us the particular terms of the French dispositive rules appropriate thereto without having to tell us how the French would classify these rules for some purpose of their own. Historically, it seems correct to say that particular dispositive rules were formulated and in use long before there was much coherent classification of such rules for any purpose, domestic or international. Professors Buckland and McNair, in their Roman Law and Common Law, tell us that: ${ }^{22}$

Both the common lawyer and the Roman jurist avoid generalizations and, so far as possible, definitions. Their method is intensely casuistic. They proceed from case to case, being more anxious to establish a good working set of rules, even at the risk of some logical incoherence which may, sooner or later, create a difficulty, than to set up anything like a logical system.

Thus, in these two great legal systems, particular dispositive rules appeared first, and the various systems for classifying them were afterthoughts. In England, there were particular rules for the form of action "assumpsit" long before any general and coherent conception of "contract" emerged, and the same can be said of the action of "trespass" in its several forms, and the concept of "tort." This is not meant as a disparagement of attempts at classification; they are valuable and essential for many reasons. Rather, the point is that here we have historical evidence in support of the assertion that a particular dispositive rule of law is not falsified or distorted in any way simply because it is isolated from one system of classification and submitted to another. However, the advocates of what is called "secondary classification" seem to postulate that there is some natural-law necessity to give foreign systems of classification priority over the English system in many matters in order to solve conflicts problems. No such necessity exists, and only confusion will result from proceeding

${ }^{20}$ This provision occurs in the respective Wills Acts of the common-law provinces, and its validity as provincial law has not been challenged. This means it is classed as a rule of "property and civil rights" (a provincial subject) and not as a rule of "marriage" (a federal subject) for purposes of the British North America Act.

${ }^{31}$ WolfF, op. cit. supra note 6 , at 146 .

${ }^{22}$ W. W. Buckinand and Arnold D. Moivair, Roman Law and Common Law xii (1936). 
on the false assumption that it does. There is no difficulty about using different systems of classification for different purposes, but confusion is certain if one attempts to use two different systems simultaneously for the same purpose, as the advocates of "secondary classification" seem to be trying to do.

Very little has been said of policy considerations in the foregoing analysis of the legal techniques or procedures involved in private international law. Every rule of law expresses policy of some kind, but in connection with private international law, some careful distinctions should be made. Given a novel situation having factual connection with two or more countries, the legally significant connecting factor for the juridical question raised has to be chosen or compounded from these factual points of contact by the judge confronted with the need to formulate a new indicative rule. In effect, he should ask himself which of the countries concerned has the most important interest in the result-which country is most closely concerned with the result. Then, the factual connecting factor which will consistently point to this particular country in such matters should be selected as the legally significant one, and, thus, a judge-made rule to that effect would emerge as a new precedent. For instance, Dr. Cheshire argues that the policy behind the choice of "the intended matrimonial home" as the legally significant connecting factor for "capacity to marry" is simply that that country is the one most closely concerned with the substantive marital standards to which the man and woman concerned should conform. Hence; it is sensible and just to frame the choice-of-law rule so that it will impose the laws of that country upon them. ${ }^{23}$ The "proper law of the contract" doctrine of England and the Commonwealth countries is (on its objective side) an even more apt illustration. This, then, is the ordinary type of policy decision which lies behind the formulation of an indicative rule of private international law and which such rules embody and express once authoritatively formulated, whether by a judge or a legislature.

This ordinary indicative type of policy decision has to be distinguished from the substantive policy considerations which govern the formulation of national dispositive laws themselves by judges or legislatures. For England, for example, monogamy is deemed desirable and right in marital relations, and, hence, English domestic laws permit only monogamy. By contrast, in India, polygamy is regarded as proper, and certain domestic Indian laws are to that effect. However, in framing a choice-of-law rule for an international marital situation touching both England and India, ordinarily the policy issue is not whether monogamy is right and polygamy is wrong or vice versa; rather, it is simply the question which country has the more important interest in the marital standards of the people concerned, whatever may be the substantive matrimonial policy expressed in that country's domestic laws. Every time foreign laws differ from English ones on a given matter and, nevertheless, are given effect in England in a particular case, English substantive policy embodied in English domestic laws is to that extent displaced by the foreign substantive policy embodied

${ }^{23}$ Cheshire, op. ct. stipra note 13, at 295-3II. 
in the foreign domestic laws. To effect this result in appropriate circumstances is the purpose of private international law. The only alternative is the intolerant and parochial one that "whoso comes to Rome must do as Romans do."

Even so, tolerance cannot be unlimited, and, thus, we find that as an extraordinary matter of ultimate reservations, substantive policy considerations do enter directly into some choice-of-law problems. "Public policy," as usually conceived in this regard, defines certain fundamentals implicit in our substantive laws and legal institutions and forbids the adoption by operation of our choice-of-law rules of any foreign laws which would work results repugnant to these basic concepts. The problem arises because our indicative rules, when they refer us to the laws of a foreign country, refer us to those laws, whatever they may be, at the material time. In this way, they rather call for a step in the dark. What ultimate public policy requires us to do is to look before we leap, and we are restrained from "taking off" if the results would be too unpalatable. For example, where Russia was the intended matrimonial home, England would have no objection to giving effect to a Russian rule that persons under 20 years are incapable of marriage, though the English age of capacity is lower. But it might be very different with the recent Soviet decree that Russians are incapable of marrying any foreign nationals. This would likely be deemed a basically repugnant type of discrimination.

It is not the ultimate or extraordinary public policy here that is an "unruly horse"; rather, the unruly horse is the uncertainty of substantive result implicit in our indicative rules, because they require us prima facie to adopt the laws of a foreign country at the material time, whatever their effect might be. The public policy reservation on the operation of these rules, then, is not the unruly horse, but the checkrein on the beast.

A further and very important point about classification of laws remains to be examined. It was said earlier, in this regard, that certain differing categories of different classification systems may logically overlap so as rationally to embrace the same dispositive rule. What must now be appreciated is that this can and does occur also between some of the classes or categories of a single classification system. Refinement of an example already used may make this more clear. Let us suppose that $A$ and $B$ marry in Redland, where both have been and continue to be domiciled. $A$ owns Blackacre, situated in Whiteland. $A$ had executed a prenuptial will leaving Blackacre to $X . A$ dies. Redland has the domestic dispositive rule that marriage revokes a prenuptial will of either spouse, but Whiteland has no such rule. The will was formerly valid by the domestic laws of either country, and in the absence of a valid will, the laws of either country would give Blackacre to $B$. $B$ and $X$ contest for Blackacre before a Whiteland court. The Redland rule quoted is logically relevant and has the possibility of being legally decisive. Moreover, as it embodies the only respect in which the relevant dispositive laws of Whiteland and Redland differ for these facts, it represents the only conflicts problem to be dealt with. Hence, classification of this Redland dispositive rule under the Whiteland conflictual 
system is necessary to define and resolve the juridical question in the Whiteland court. But suppose that we find that the Whiteland conflictual system contains the following two indicative rules: (i) succession to proprietary interests in immovables, inter vivos or on death, is governed by the law of the country where the immovable is situated; and (ii) all matrimonial rights and duties of spouses, either inter vivos or on the death of one spouse, are determined by the law of their domicile as married persons at the material time. Now, is the Redland dispositive rule in question to be characterized as a rule of succession to proprietary interests in immovables, or is it a rule defining matrimonial property rights of spouses? In the former case, rule (i) operates and points to. Whiteland, the antenuptial will is valid, and $X$ owns Blackacre. In the later event, rule (ii) operates and points to Redland, the will is void, and $B$ is the owner of Blackacre. Logically, the rule to be classified is as much a rule of land succession rights as it is a rule of matrimonial rights. But how is the Whiteland court to choose between these semantically equal alternatives?

At this point, analytical reasoning ceases to help. It becomes functus officio in having displayed the alternatives. To effect a choice between them, considerations of value and purpose must be introduced, which is another way of saying that reasons of policy must now govern. As was said, the basic purpose of a conflictual system is conflict avoidance in the sense that the persons involved in a set of international facts should enjoy the same legal position on those facts in each country in truth connected therewith. The nature of each country's conflictual rules indicates the terms on which it considers this uniformity of result should be sought, not only by itself, but by others as well. (Whether other countries are respectively found to agree when the nature of their conflictual rules is examined is another question, to be explored later.) But when the indicative rules of a single conflictual system are ambiguous because of overlapping categories for the classification of laws, as in the example given, what is the policy question involved? In this position, the Whiteland court must ask itself: Which is the more important of the two juridical aspects presented by this dispositive rule about revocation of a prenuptial will, the aspect of land ownership or that of matrimonial rights? In other words, where one must choose, is it better to pursue international uniformity of result for particular juridical martimonial-land issues on the basis of situs (the land rights connecting factor) or domicile (the matrimonial rights connecting factor)? If one makes the latter decision, in favor of the matrimonial classification and domicile, this necessarily means that one judges the policy behind domicile as a connecting factor to be more appropriate for matrimonial-land questions than the policy behind situs as a connecting factor. Uniformity of result, in the sense explained, can be sought on either basis, but the question is, on which terms is it preferable to have it come, situs or domicile? Domicile of spouses should point to the country with the greatest social and moral interest in the substantive terms of their legal relations. Situs of land points to the country which, as a practical matter, has the last word on the enforcement of the land rights in question, and which, of 
course, also has very real social and economic interest in the substantive terms on which such a parcel of land is to be held. The foregoing assumed decision in favor of the greater significance of the matrimonial aspect (classification) amounts to deciding that the state of matrimonial rights (laws) in general is more important than the state of land ownership rights (laws) in general, and, hence, in these circumstances, domicile is to be preferred to situs in private international law. This means that possible impracticability of enforcing matrimonial rights respecting land is to be risked in order to refer this issue, along with all other types of matrimonial issues, to the dispositive law of the country of domicile.

Lest it be considered that too much of this reasoning rests upon a single example, there are others. In discussing the classic English case of Cammell v. Sewell, ${ }^{24} \mathrm{Dr}$. J. H. C. Morris asks why, for conflictual purposes, were those facts considered to involve a juridical issue of "ownership" rather than "tort"? 25

There is one tort to which the courts seldom apply the law of the place of tort, and that is the tort of conversion. That this is so abundantly appears from typical leading cases. In Cammell v. Sewell, lumber belonging to P, an Englishman, was shipped to England from a Russian port on board a Prussian ship. The ship was wrecked off the coast of Norway and the master sold the lumber to D, a Norwegian, in circumstances which conferred a good title on D by Norwegian but not by English law. D brought the lumber to England and refused to deliver it to $\mathrm{P}$ on demand. $\mathrm{P}$ brought an action of trover against $D$ in England, claiming damages for conversions. The action was dismissed on the ground that D's Norwegian title prevailed. Yet the conversion (demand and refusal) undoubtedly took place in England.

In terms of this present analysis, the classification problem for the English court in Cammell v. Sewell under the English conflictual system was whether the relevant English dispositive rules concerning conversion of chattels were to be classed as "proprietary" or "tortious." Semantically, all you can say is that these dispositive rules are either or both. Conversion in the common law is the flouting of title. The English court, in effect, decided that the proprietary aspect of these rules was more important than their tortious aspect and, hence, decided title by Norwegian law. Accordingly, the general point of critical importance that emerges from the foregoing is that, because of the logical bivalence or polyvalence of dispositive laws for classificatory purposes, even within a single classification system, one never achieves "the exact disjunctions of a perfect logical scheme." True enough, priorities between overlapping categories for classification of laws may be established by precedent (no doubt Cammell v. Sewell does this in England for conversion of chattels), and the scope of such categories may be thus refined and particularized to eliminate some ambiguity. Nevertheless, it is submitted that some overlapping inevitably will remain. The bivalence or polyvalence of particular dispositive rules for classificatory purposes will always assert itself in some degree as an intractable element, even

${ }^{24} 5$ H. \& N. 728, 157 Eng. Rep. 137 (Ex. 1860).

${ }^{25}$ Morris, The Proper Law of a Tort, 64 HaRv. L. Rev. 88I, 886 (195I).

${ }^{20}$ Viscount Haldane, L. C., in John Deere Plow Co. Ltd. v. Wharton, [1915] A. C. 330, 338-39. 
within a single conflictual system. Not much attention has been paid to this factor in private international law, but its nature has been much more fully appreciated and explored in the constitutional law of federal states, where the same kind of system for classification of dispositive laws has to be employed to distribute legislative powers between a central legislature on the one hand and state or provincial legislatures on the other. ${ }^{27}$

\section{IV}

\section{Conflict Avoidance and the Problems of the Comprehensive Reference TO FOREIGN LAW}

As has been said, the basic policy of a national conflictual system is to effect a general uniformity of result in different countries in a given international situation, such uniformity to be on the terms of the dispositive law of the country with the greatest interest in the legal relations at issue for the persons involved. When an English court under the English conflictual system turns to French dispositive law to determine the essential validity of a contract, it does so in the hope that a French court would agree that France is the country most closely concerned and would likewise apply French dispositive law to determine the same issue. There is, of course, no way the English courts, or Parliament for that matter, can ensure this result in framing English rules for choice of law. They can but hope that a French court would be directed by French conflictual rules to the same effect. In any event, to treat this English reference to French law as embracing French dispositive law only is the logical culmination of the conflictual technique and procedure that has been analyzed in the preceding parts of this article. As we have seen, it was, in part at least, the possible decisiveness of the French dispositive rules found to be relevant to the facts in the first place that caused the English court to determine that the juridical question for it was one of the essential validity of a contract. If, then, the appropriate English connecting factor for this type of question points to France, that surely should mean that the relevant French dispositive rules are now to be decisive of the issue, to the exclusion of the corresponding rules of any other country. It appears that Dr. Cheshire would agree, for he says: $:^{28}$

It is illogical that a selective rule concerned with a given situation should be abandoned in favour of a foreign rule of selection concerned with the same situation. If this is to be done, then rules for the choice of law become to a large extent meaningless. . . . A rule of selection which selects another rule of selection is no doubt possible, but to attribute this character to a rule for the choice of law is scarcely sensible.

Nevertheless, the comprehensive reference to foreign law, that which includes the foreign conflictual system, has, at times, been judicially sanctioned. ${ }^{29}$ Space does

${ }^{27}$ The writer has expounded his views on the classification of laws and the federal constitution of Canada in an essay entitled Classification of Laws and the British North America Act, in Legar Essays in HoNOUR OF ARTHur MOXON 183 (I953).

${ }^{28}$ Cheshire, op. cit. supra note 14 , at 94 .

${ }^{20}$ See Re Annesley, [1926] Ch. 692; Re Ross, [1930] I Ch. 377; Re Askew, [1930] 2 Ch. 259; Re O'Keefe, [1940] Ch. I24; Re Duke of Wellington, [1947] Ch. 506, [1948] Ch. II8. 
not permit full development here of the problems that then arise, ${ }^{30}$ but they may be briefly mentioned. Such a comprehensive reference, e.g., by an English court to French law, raises the possibility of a conflict of conflict rules if it happens that the appropriate French conflictual rule differs from the English one in a manner critical for the situation of fact under review. Conflictual rules relevant to the same international situation of fact may differ in their categories for classification of dispositive laws or their connecting factors or both. A renvoi dilemma (a sterile oscillation of references between the two conflictual systems) may then be set up, and for this, no rational or predictable solution is really possible. Further, if the conflicting conflictual rules differ in their respective categories for the classification of laws, then the problems of secondary classification, so-called, present themselves, whether or not there is renvoi. Rabel says secondary classification means "characterization by the lex fori for choice of law-characterization by the foreign law once chosen."31 In this writer's opinion, secondary classification is quite impossible as an element in the legal technique of a conflictual system. ${ }^{32}$ Two different systems of classification of laws cannot be used simultaneously for one and the same purpose. When and how and why are the English to give the French system of classification priority over their own in attempting to effect conflict avoidance in the sense explained? There just are no satisfactory answers. Renvoi dilemmas and problems of secondary classification, when they occur, are pathological in significance. They indicate that the limits of effectiveness of the national conflictual system of the forum have been left behind. The comprehensive reference is quite haphazard and unpredictable in its effects, and, hence, it is simply not a feasible legal indicative technique.

$\mathrm{V}$

Theories of the Nature of Private International Law-Conclusions about Conflict of Avomance by International Agreement

We may now conclude that, so long as conflict avoidance is being attempted purely at the national level, each country should stay with its own classification system and make no reference whatever, at any stage, to a foreign conflictual system. Though the results be far from perfect, this represents the best chance for effective conflict avoidance under a national indicative system. In effect, each country, in its conflictual system, announces the terms on which it will itself refer to foreign dispositive law to attempt conflict avoidance and then hopes for reciprocity. The English conflictual rule that the right to divorce should be settled in accordance with the dispositive law of the country of domicile of the spouses, in effect, says that, in the English view, the country of domicile is the one most closely concerned on social and moral grounds with this type of legal issue, and, hence, it is the English hope that all countries would be willing to proceed on the basis of domicile for such

\footnotetext{
${ }^{30}$ The writer's views in this respect are much more fully set out in Lederman, supra note 13, at 168 et seq.

31 I Rabel, op. cit. supra note 12, at 65 .

${ }^{32}$ It seems Dr. Marsh agrees. See MARSH, op. cit. stipra note 13 , at 85-91.
} 
juridical issues. This hope or expectation suggests how valuable true uniformity of national conflictual systems would be. Such uniformity would prevent prenatally secondary classification and renvoi dilemmas. Moreover, it would give real assurance of the same legal results on international facts in the different countries concerned on the basis of the dispositive law of that one of them agreed to be the one with the greatest interest in the state of the legal relations at issue. If both England and France say that title to a chattel is to be determined by the law of the country where the chattel was situate when the transaction alleged to concern its title occurred, and both countries mean the same thing by "title," "chattel," and "situs," then uniformity will result in the legal state of title on terms of the dispositive law of the country of situs at the material time. This should be so whether the question is put to an English or a French court. Of course, uniformity of the national dispositive laws themselves would be the ultimate in conflict avoidance, but, except to a limited degree, this is not a practical goal. On the whole, citizens of national states will tend to insist both on maintenance of their own respective dispositive laws, and on unfettered national legislative power to alter them unilaterally. And so, while there have been some notable examples of negotiated uniformity of dispositive laws between different countries, this does not seem to present a solution of really wide scope or range in the near future. Instead, the comprehensive solution for conflict avoidance would seem rather to be uniformity of the various national conflictual rules so that, in effect, there would be one overriding indicative system really worthy of the title "private international law." How much uniformity is there now in this respect, and what steps are necessary to bring about more of it? Might more uniformity come as an all-pervasive natural law on the subject is progressively uncovered by comparative studies, or is conscious and painstaking effort at international agreement necessary?

In attempting to answer these questions, it is necessary to look briefly at the two principal theories current about the nature of our present systems of private international law. These are known as the "vested rights" theory and the "local rights" theory. Professor Beale has stated the "vested rights" theory as follows: "A right having been created by the appropriate law, the recognition of its existence should follow everywhere. Thus an act valid where done cannot be called in question anywhere."33 Accordingly, it is admitted that the operation of national laws is territorial in scope, but it is said that rights, once vested by the appropriate law, can, in effect, walk abroad with their owners and must necessarily be accorded recognition by other territorial legal systems. Thus, Dr. Schmitthoff, a modern advocate of this theory, speaks of "the distinction between foreign law which is not entitled to enforcement in the English jurisdiction, and rights created by that foreign law, which generally are protected by the English courts." 34 So, not only are rules of private international law necessary to define the various legal aspects of concrete facts and to

${ }^{33} 3$ Joseph H. Beale, A Treatise on the Conflict of Laws 1969 (r935).

34 C. M. Schmitthoff, A Textbook on the English Conflict of Laws io (2d ed. 1948). 
assign them to their appropriate territorial legal systems, but this theory goes further and necessarily presumes that there are universal and uniform tests valid for all national legal systems whereby this task of definition and allocation can be implemented. This must be so if one country is under compulsion to recognize rights "created" or "vested" by another. Such principles, if they existed, would need to take one of two forms: they might be part of a genuine international law binding all countries; or they might be embodied in universally valid principles of legal logic the consistency of which was compelling enough to control the content of the various national systems of private international law. This latter view is really a natural-law conception. However, either way, the basic postulate of the pure "vested rights" theory is that conflictual choice-of-law rules are part of a supernational system which is uniform for all countries and binding on all countries.

In contrast to this, we have what has been called the "local rights" theory, brilliantly advocated by Professor W. W. Cook ${ }^{35}$ and accepted by Dr. Cheshire. ${ }^{30}$ It is to the effect that a legal right is completely the creature of a particular national legal system, and, thus, the right, as such, cannot exist in any legal sense outside the territory where the legal system that creates and maintains it is operative. Accordingly, this theory asserts that the only rights which exist and are enforceable in England are rights created by English law. But, when confronted with facts having foreign features, the private international branch of English law frequently does accord some significance to relevant foreign principles of law to the extent that it is consistent with English ideas of policy, convenience, and justice so to do. Thus, where a set of facts has certain connections with France, English private international law, on some legal aspect of the facts which it defines, may operate so as to create an English right as closely equivalent as possible to that which the French law would confer in France on the same facts. This does not mean that French rights as such cross the channel with their owners and must then be accorded recognition in England. Neither does this theory postulate supernational and uniform conflictual choice-of-law rules. Rather, the "local rights" theory asserts that each national state controls for itself the content of its own private international law. Hence, conflictual rules of the various national states will often differ, and uniformity in this respect, when it occurs, does so for historical or conventional reasons, i.e., because certain different countries have a common legal inheritance or have specifically agreed on some uniformity of conflictual rules.

From all that has been said hitherto, it is apparent that the present writer accepts the "local rights" theory as the more accurate hypothesis explaining the present position. Nevertheless, the "vested rights" theory does assert correctly what must be the basic policy or purpose of any conflictual system-that persons involved in international situations of fact should be able to enjoy the same legal relations in all countries touched by those facts. The uniformity of conflictual systems this theory

\footnotetext{
${ }^{35}$ CoOK, op. cit. supra notc 5 , at 20,21 .
}

${ }^{38}$ Cheshire, op. cit. stipra note 14 , at 54 . 
postulates embodies this view of policy and purpose. But jurists advocating the "vested rights" theory are wrong to assert either that we necessarily have such uniformity now or that a natural uniformity will emerge as soon as a sufficient number of lawyers, judges, and jurists immerse themselves in relevant comparative juridical studies. As we have seen, there is no one "natural" classificatory system for dispositive laws. Neither is it obvious which of several possible connecting factors is the most appropriate one for this or that type of juridical question. Uniformity is the great desideratum, but except to the extent that it obtains now between different jurisdictions for historical reasons, it must be consciously and painstakingly contrived by international agreements or conventions of some kind. The attempt in this article has been to reveal the elements that would necessarily be involved in the task of reaching international agreements effective to this end, and now, by way of conclusion, they may be recapitulated in a summary way.

An international agreement that seeks to establish effective uniformity of national conflictual systems must take account of the following considerations:

(I) There must be agreement in detail on the policy issues of a conflictual system. One must determine which classes of legal relations (dispositive laws) are to be employed and then, in respect of each of these classes, which connecting factor would consistently point to the country with the greater or greatest interest in the state of the legal relations of the persons concerned. Specific examples of these policy problems have already been given. Suffice it to say at this point that mere verbal identity in conflict rules is not enough. Each uniform rule needs to express real agreement reached after facing the basic issues of policy involved. The main purport of this article is that such agreements are not only possible, but necessary, and that they are not inhibited by any "natural" priorities for this or that classification system or connecting factor. Uniformity can be and, indeed, must be consciously contrived, except, of course, where it already obtains for historical reasons. Even in the latter event, it may well be desirable to have uniformity on new indicative rules rather than on the old basis.

(2) There must be some agreed limitation on the extraordinary public policy reservations that have been described. When one of these reservations arises under national auspices, it renders inoperative the relevant national conflictual rule which would refer the matter concerned abroad and compels decision on the basis of the national dispositive law of the forum. This is so, as we have seen, because there are some legal relations where the substantive policy of the local dispositive law is deemed so fundamental that it is not permitted to give way by ordinary conflictual principles to foreign solutions that are too far inconsistent with the local one. Clearly, a discretionary exception of this kind in national hands could go far to nullify the effective operation of an agreed uniform system of private international law.

(3) The classification categories for dispositive laws adopted for an agreed uniform system should be technically as scientific as possible, in the sense that the 
overlapping of categories is held to a minimum. Nevertheless, the bivalance or polyvalence of individual dispositive rules themselves will be manifest to some degree within the classificatory scheme of any conflictual system. Anyway, agreement might not be possible on the analytical scheme that holds the best promise semantically of eliminating the overlap of categories. Something less than the best, in this respect, might have to be accepted to get agreement at all. As has been said, this intractable element in indicative technique has been little noticed in private international law, though clearly recognized in the jurisprudence of federal constitutions. To revert to the example about matrimonial property given earlier, England and France might entirely agree in attributing matrimonial rights to domicile and land rights to situs, and yet they might still differ in classifying the rule that "marriage revokes a prenuptial will of either spouse." England might call it a rule of land rights, while France called it a rule of matrimonial rights. This would not mean that they differed in their substantive definitions of these two conflictual rules-just that they differed on which was the leading feature of a dispositive rule that is a rule both of matrimonial and land rights.

The foregoing three points suggest certain further conclusions. In the first place, effective operation of an agreed uniform conflictual system would seem to require that all countries under the system submit themselves to a common, authoritative, and highly qualified tribunal of interpretation. To this tribunal, appeal might be taken from national courts when an important issue on the meaning of the agreed conflictual rules arose. This would ensure that verbal identity would also be substantial identity of definition. Also, it would mean that specified limits on extraordinary public policy reservations would receive common and restrictive interpretation. Furthermore, only such a tribunal could eliminate the ambiguity introduced by the bivalent or polyvalent character of most dispositive rules. Authoritative interpretation-one single final voice-is the only good answer, as a matter of legal technique, to this last problem. For all these reasons, then, international agreements looking to conflict avoidance in the sense explained should provide for such a tribunal.

The second of these concluding points is simply that progress along the lines envisaged here clearly means much study of comparative law, or, if you prefer, of comparative legal science and philosophy. The need to agree upon a common classification system for dispositive laws makes this obvious. But if the student of comparative jurisprudence pursues the will-o-the-wisp of the one naturally valid set of conflictual rules, his contribution to conflict avoidance will be distorted and limited.

Finally, as has been noted, there is a significant degree of uniformity of national conflictual systems by reason of common legal inheritance. This is particularly true between common-law jurisdictions of the British Commonwealth, not only because of legal history, but also because the leads given by the English courts in private international law have been widely followed in the Commonwealth. Indeed, it is interesting to speculate just to what extent this sort of historical uniformity has 
really made the conflict avoidance game worth the candle at the national level. In any event, such historical uniformity is very valuable, and there should be much hesitation over changes that would impair or destroy it. Unilateral national change of common-law rules, or international agreements partial as to contents or parties, might easily do more harm than good as far as effective conflict avoidance is concerned. ${ }^{37}$

${ }^{37}$ Dr. E. J. Cohn, in an article entitled Domicile-Convention and Committee, 7x L. Q. Rev. 562 (1955), foresees serious difficulties in connection with the Draft Convention to Regulate Conflicts between the Law of Nationality and the Law of Domicile, accepted at The Hague in I95I. He detects a failure to agree fully on the meaning of domicile so far as England is concerned and analyzes the prospective unfortunate consequences of this. 


\section{•}

